\title{
AUTHOR INDEX VOLUME 11 (1993)
}

(The issue number is given in front of the page numbers)

Alemna, A.A., Professional education and subsequent careers: a follow-up study of former students of the Department of Library and Archival Studies, University of Ghana, Legon

(1) $\quad 57-63$

Anderson, D. and R. Newton, Putting students in the picture (Short Communication)

(4) $331-337$

Ashoor, M.S., see A.S. Chaudhry

(1) $47-56$

Beheshti, J., Computer programming in LIS education: a necessity?

Cartwright, G.F., see M. Silva

(2) $123-136$

Chaudhry, A.S., M.S. Ashoor and S.U. Rehman, Development and implementation of an in-house continuing education program in an academic library

(2) $137-146$

Clark, A.J., Education and training for librarianship and information work: Annual bibliography, 1992

(1) $\quad 47-56$

Cochrane, C., The reactions of lecturers to the potential use of computer conferencing

(3) $217-272$

Correia, A.M.R. and T. Wilson, The development of the European information market through education and training - the Portuguese experience

(4) 307-319

Curras, E., Information science in the Universidad Autónoma de Madrid: developments with the times

(4) $297-305$

Dou, H., P. Hassanaly, L. Quoniam and A. La Tela, Technology watch and competitive intelligence: a new challenge in Education for Information

(3) $205-215$

Duval, B.K. and L. Main, Library education for literacy librarians

Farah, B.N., Teaching data communications and computer networks: a course description

(1) $\quad 35-45$

(2) $105-121$

Figueiredo, N., Continuing education in Brazil: overview from the past and perspective for the future

(2) $97-104$

Futas, E., see F. Zipkowitz

(4) $321-329$

(1) $\quad 19-34$

Hassanaly, P., see H. Dou

(1) $\quad 35-45$

Horton, W.J., Research methods and data gathering techniques in the arts and social sciences (Short Communication)

(1) $\quad 65-67$

Lazinger, S.S. and B.C. Peritz, Managing multilinguality: Israel's retraining course for new immigrant librarians

(3) $181-188$

Main, L., see B.K. Duval

(2) $105-121$ 
Newton, R., see D. Anderson

(4) $331-337$

Ochogwu, M.G., Producing the basic competencies in information science education in Nigeria

(2) $147-154$

Peritz, B.C., see S.S. Lazinger

(3) $181-188$

Quoniam, L., see H. Dou

(1) $\quad 35-45$

Rehman, S.U., see A.S. Chaudhry

(1) $\quad 47-56$

Roberts, B., Librarians in the new Europe: training and education needs of librarians working in national libraries

(4) $283-288$

Robertson, J.E. and D.A. Williams, Information skills in Further Education: a business sturdies perspective

(4) $289-296$

Rowland, F., see D. Stephens

(3) $189-204$

Silva, M. and G.F. Cartwright, The design and implementation of Internet seminars for library users and staff at McGill University

Stephens, D. and F. Rowland, Initial IT training in Departments of Information and Library Studies in the British Isles: a survey of student views

(2) $137-146$

Tela, A. La, see H. Dou

(3) $189-204$

Wade, S., Papers: a simple object-oriented text retrieval system

(1) $35-45$

Williams, D.A., see J.E. Robertson

(1) $\quad 3-17$

Wilson, T., see A.M.R. Correia

(4) $289-296$

Zipkowitz, F. and Futas, E., Faculty replacements in library schools

(4) $297-305$

(1) $\quad 19-34$ 